\title{
Development of the N-Doped Cu-Carbon Composite as a Novel Catalyst for the Removal Reactive Black 5
}

\author{
Nargish Jahan Ara1, Mohammad Farhadur Rahman ${ }^{*}$, Zubair Hasan ${ }^{2 *}$, Md. Shofiqul Islam³, \\ Mohammad Mahbubur Rahman ${ }^{4}$
}

${ }^{1}$ Department of Chemistry, Bangladesh University of Textiles, Dhaka

${ }^{2}$ Department of Mathematics and Physical Science, East West University, Dhaka

${ }^{3}$ Department of Pharmacy, East West University, Dhaka

${ }^{4}$ Fiber \& Polymer Research Division, BCSIR Laboratories, Dhaka

Email: *zhasan@ewubd.edu, *chemistry.butex2010@gmail.com

How to cite this paper: Ara, N.J., Rahman, M.F., Hasan, Z., Islam, M.S. and Rahman, M.M. (2020) Development of the N-Doped $\mathrm{Cu}$-Carbon Composite as a Novel Catalyst for the Removal Reactive Black 5. Open Journal of Applied Sciences, 10, 432-443. https://doi.org/10.4236/ojapps.2020.107030

Received: February 3, 2020

Accepted: July 14, 2020

Published: July 17, 2020

Copyright $\odot 2020$ by author(s) and Scientific Research Publishing Inc. This work is licensed under the Creative Commons Attribution International License (CC BY 4.0).

http://creativecommons.org/licenses/by/4.0/

\begin{abstract}
In this study, two $\mathrm{Cu}$-based catalysts with and without $\mathrm{N}$ doped carbon matrix, named $\mathrm{N}-\mathrm{Cu} / \mathrm{CuO} / \mathrm{C}$ and $\mathrm{Cu} / \mathrm{CuO}$ were synthesized via calcination of melamine-cupper acetate complex and cupper acetate at $500^{\circ} \mathrm{C}$ under an inert atmosphere. The catalysts were characterized by X-ray powder diffraction (XRD), Field Emission Scanning Electron Microscope (FESEM), and CHNS elemental analyzer. The catalytic activity of both catalysts was evaluated through the $\mathrm{NaBH}_{4}$ associated reduction of commercial textile dye named reactive black 5 (RB5). The kinetics of the reduction of reactive black 5 was also described by the pseudo-first-order kinetic equation. For the studied reduction, $\mathrm{N}-\mathrm{Cu} / \mathrm{CuO} / \mathrm{C}$ exhibited enhanced catalytic activity both in conversion and kinetics ( $97 \%$ conv. in $315 \mathrm{sec}$ ) compared to that of by $\mathrm{Cu} / \mathrm{CuO} / \mathrm{C}$ ( $25 \%$ conv. in $1500 \mathrm{sec}$ ). Besides, $\mathrm{N}-\mathrm{Cu} / \mathrm{CuO} / \mathrm{C}$ also demonstrated good reusability up to four consecutive cycles.
\end{abstract}

\section{Keywords}

Catalytic Reduction, Reactive Black 5, Non-Noble Metal Carbon Composites, Calcinations

\section{Introduction}

A huge amount of wastewaters having various synthetic dyes are generated worldwide because of their widespread use in the industry [1]. Every year approximately $8 \times 10^{5}$ tons of around 100,000 commercially available dyes are manufactured worldwide, which are widely used in various industries such as textile, 
pharmaceutical, cosmetics, food, and so on [2]. Among various commercial dyes, azo dyes are widely used dyes that cover around $70 \%$ of the world dye production [3]. Around $70 \%$ of the aqueous wastes generated from textile industries are due to the use of azo dyes [4]. These textile waste water (concentrations between 10\% - $15 \% \mathrm{w} / \mathrm{v}$ ) should be discharged into different natural aquifers after proper treatment, however, many of the industries especially in third world country regularly discharge such wastewater without proper treatment [5].

Reactive Black 5 (RB5) is one of the most widely used azo dyes due to its high chemical stability along with enhanced water solubility [6] [7]. RB5 is a common reactive dye generally used to dye wool, nylon, cotton, and other cellulosic fiber [7]. In most cases, dyes do not completely fix the fabric which resulted in the generation of toxic aqueous waste [6]. These azo dyes are toxic and carcinogenic as a consequence, the wastewater with synthetic dyes can induce severe adverse effects such as carcinogenesis, mutagenesis in humans [8]. Moreover, the existence of a very small amount of dye in the water can alter the water transparency due to their high visibility that might adversely affect the aquatic life by sunlight to pass through the water [9].

At these circumstances, it is essential to develop methods and materials to remove these coloring contaminants from the aqueous media. So far, various methods have been applied to remove RB5 from water such as photo-catalytic degradation [10], Fenton/Fenton-like processes [11], biological treatments [12], electrochemical processes [13], electro-oxidation [14], ozonation [15], $\mathrm{UV} / \mathrm{H}_{2} \mathrm{O}_{2}$ oxidation [16], etc. Nevertheless, many of these techniques suffer from several shortcomings such as extended operation time, lower efficiency, and high cost. To overcome such shortcomings, researchers have focused on the development of new methods. Recently, such as $\mathrm{NaBH} 4$ assisted reductive decolorization using metal-based catalysts have drowned a great deal of attention [17]. In this method, so far, mostly noble metals based catalysts such as Au, Pd, Pt etc. have been widely used [17]. However, to reduce the cost, attempts to develop nonnoble based catalysts such as $\mathrm{Cu}$ [18], Co [19], and $\mathrm{Ni}$ [20] were also encountered. Moreover, the catalytic activity of metals found to enhanced significantly when these metals were embedded in the $\mathrm{N}$ doped carbon matrix [21]. The presence of $\mathrm{N}$ atoms may enhance the electron density in the carbon architecture, which eventually improves the electrical properties as well as surface reactivity [21] [22] [23].

In this study, a novel approach to prepare $\mathrm{N}$ doped copper carbon catalyst is investigated utilizing low-cost and readily available chemicals, copper acetate monohydrate, and melamine via heat treatment under an inert atmosphere. The catalytic performance of prepared catalysts was evaluated by the $\mathrm{NaBH}_{4}$ assisted catalytic reduction of RB5.

\section{Experimental}

\subsection{Materials}

All reagents and solvents are commercially available and were used without fur- 
ther purification. Copper (II) acetate monohydrate $\left(\mathrm{Cu}\left(\mathrm{C}_{2} \mathrm{H}_{3} \mathrm{O}_{2}\right)_{2} \cdot \mathrm{H}_{2} \mathrm{O},>98 \%\right)$, melamine $\left(\mathrm{C}_{3} \mathrm{H}_{6} \mathrm{~N}_{6},>98 \%\right)$ were purchased from Sigma Aldrich. Sodium borohydride $\left(\mathrm{NaBH}_{4}\right.$, extra pure), methanol $\left(\mathrm{CH}_{3} \mathrm{OH}, 99.5 \%\right)$, ethanol $\left(\mathrm{C}_{2} \mathrm{H}_{5} \mathrm{OH}\right.$, 99.9\%) were purchased from Daejung chemical, South Korea. The dye, reactive black $5\left(\mathrm{C}_{26} \mathrm{H}_{21} \mathrm{~N}_{5} \mathrm{Na}_{4} \mathrm{O}_{19} \mathrm{~S}_{6}\right)$ was supplied by Dye Star Ltd., Dhaka, Bangladesh.

\subsection{Synthesis Cu-Mel Composites}

$25 \mathrm{ml}$ water and $5.0 \mathrm{~g}$ of melamine were taken in a $200 \mathrm{ml}$ round bottom flask and the solution are sonicated for $10 \mathrm{~min}$ at room temperature. The sonication resulted in the formation of white suspension where $1 \mathrm{mmol}$ Copper (II) acetate monohydrate was added. The reaction mixture was further stirred using a magnetic hotplate stirrer at $100^{\circ} \mathrm{C}$ under reflux condition for $3 \mathrm{~h}$. After that, the solids were filtered and kept in a conventional drying oven at $105^{\circ} \mathrm{C}$ for $12 \mathrm{~h}$. After drying, the collected samples were stored for further heat treatment. The sample in this stage is denoted as $\mathrm{Cu}-\mathrm{Mel}$ composites.

\subsection{Synthesis of $\mathrm{N}$-Doped $\mathrm{Cu} / \mathrm{CuO}_{2} /$ Carbon Composites}

$1.0 \mathrm{~g}$ prepared $\mathrm{Cu}-\mathrm{Mel}$ composites were taken in high temperature alumina crucible $\left(14 \mathrm{H}^{\star} 18 * 75 \mathrm{~L} \mathrm{~mm}\right)$, which as placed in a tubular furnace. A $700 \mathrm{~mm}$ long alumina tube with $40 \mathrm{~mm}$ outer diameter was used as a tubular reactor. The $\mathrm{Cu}-\mathrm{Mel}$ composites were heated at $500^{\circ} \mathrm{C}$ under an inert atmosphere. The heating was set to $5^{\circ} \mathrm{C} / \mathrm{min}$ and the temperature was monitored using a $\mathrm{K}$-type thermocouple. The inert atmosphere was maintained using a constant flow of $\mathrm{N}_{2}$ gas at a rate of $30 \mathrm{~mL} / \mathrm{min}$ throughout the reaction. After the reaction, when the temperature went down to room temperature, the black powder samples were collected, washed several times with methanol-water mixture and stored for next use in closed $20 \mathrm{~mL}$ vial. The synthesized composites were donated as $\mathrm{N}$-doped $\mathrm{Cu} / \mathrm{CuO}_{2} / \mathrm{Carbon}(\mathrm{N}-\mathrm{Cu} / \mathrm{CuO} / \mathrm{C})$ composites. A similar method was adopted for calcination of $\mathrm{Cu}\left(\mathrm{C}_{2} \mathrm{H}_{3} \mathrm{O}_{2}\right)_{2} \cdot \mathrm{H}_{2} \mathrm{O}$ and the obtained black powder was named as $\mathrm{Cu} / \mathrm{CuO}$ composites.

\subsection{Characterization}

X-ray powder diffraction (XRD) analysis was conducted with the Rigaku DMax-2500 diffract meter using $\mathrm{CuK} \alpha$ radiation. The morphologies and composition of the samples were examined with a field emission scanning electron microscopy (FE-SEM, JEOL-JSM7401F). An elemental analyzer (Thermo Fisher, Flash-2000) equipped with a TCD detector was used to measure the nitrogen content of the catalysts.

\subsection{Reduction of Reactive Black 5 (RB5)}

The catalytic reduction of RB5 was carried out in a standard quartz cuvette with $1 \mathrm{~cm}$ path length in the presence of an excess amount of $\mathrm{NaBH}_{4}$ at room temperature, and the progress of the reduction was monitored using a UV-vis spec- 
troscopy (Shimadzu-1800). A $10 \mathrm{mg} / \mathrm{mL}$ aqueous dispersion of $\mathrm{N}-\mathrm{Cu} / \mathrm{CuO} / \mathrm{C}$ was prepared to use as a catalyst. First, $0.2 \mathrm{~mL}$ of $80 \mathrm{ppm}$ RB5 mixed with $2.5 \mathrm{~mL}$ DI water, and then, $0.2 \mathrm{~mL}$ of varying concentrations of the freshly prepared $\mathrm{NaBH}_{4}$ solution was added to the cuvette. After that, $100 \mu \mathrm{L}$ of the prepared dispersion was added to the cuvette, and the solution was quickly introduced to UV-vis measurements. The absorbance of the solutions was measured at different intervals within the scanning range of $400-750 \mathrm{~nm}$. The kinetics data of RB5 reduction were obtained by monitoring the absorbance at $598 \mathrm{~nm}$.

\section{Results and Discussion}

\subsection{Characterization of the Composites}

Figure 1 presents the $\mathrm{XRD}$ pattern of the composites prepared from $\mathrm{Cu}$-melamine and copper acetate monohydrate, respectively. After calcination at $500^{\circ} \mathrm{C}$, both of the precursors resulted in the formation of composites having metallic $\mathrm{Cu}$ and cubic $\mathrm{CuO}$ phases.

Both of the composites, $\mathrm{N}-\mathrm{Cu} / \mathrm{CuO} / \mathrm{C}$ and $\mathrm{Cu} / \mathrm{CuO}$, exhibited three peaks evolved at $43.3^{\circ}, 50.3^{\circ}$ and $74.1^{\circ}$, which might be ascribed to the (111), (200) and (220) planes of metallic copper (JCPDS No: 4-0836), respectively [24] [25]. On the other hand, peaks exist at $38.9^{\circ}$ and $66^{\circ}$ might be attributed to the (111) and (31-1) phase of the monoclinic CuO phase ((JCPDS card No. 48-1548) [26]. No diffraction peaks of any $\mathrm{Cu}_{2} \mathrm{O}$ phases were observed in the diffraction pattern of both composites.

SEM images of the prepared composites were used for the further illustration of the morphology of $\mathrm{N}-\mathrm{Cu} / \mathrm{CuO} / \mathrm{C}$ and $\mathrm{Cu} / \mathrm{CuO} / \mathrm{C}$ composites. As depicted in Figure 2(a), the $\mathrm{Cu} / \mathrm{CuO} / \mathrm{C}$ seemed to be many aggregated particles comprising of a great amount of irregular small crystals. This agglomeration might be due to the high-temperature calcination of the solid precursors. However, agglomeration was more prone in $\mathrm{N}-\mathrm{Cu} / \mathrm{CuO} / \mathrm{C}$ composites as shown in Figure $2(\mathrm{~b})$. Besides, a little bit of layered type morphology was noticed in $\mathrm{N}-\mathrm{Cu} / \mathrm{CuO} / \mathrm{C}$ which might be the presence of melamine in the precursor as the thermal condensation of melamine generally occurred during the heat treatment that usually resulted in the formation of the layered structure [27].

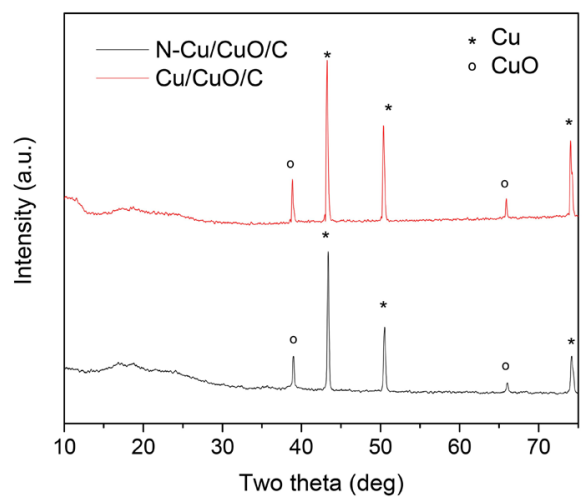

Figure 1. XRD patterns of $\mathrm{N}-\mathrm{Cu} / \mathrm{CuO} / \mathrm{C}$ and $\mathrm{Cu} / \mathrm{CuO}$ composites. 


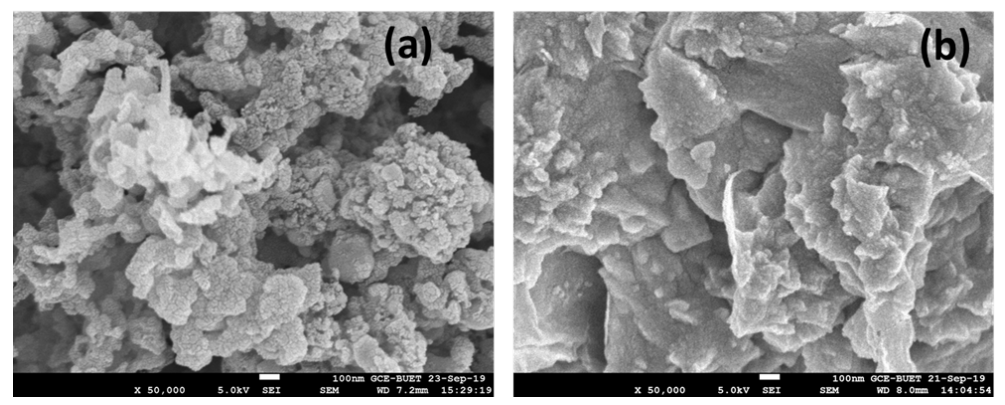

Figure 2. FE-SEM images of (a) $\mathrm{Cu} / \mathrm{CuO}$; (b) N-Cu/Cu/CuO .

In both synthesis, $\mathrm{Cu}\left(\mathrm{C}_{2} \mathrm{H}_{3} \mathrm{O}_{2}\right)_{2} \cdot \mathrm{H}_{2} \mathrm{O}$ was as the source of metal or metal or metal oxide. However, melamine has been used during the synthesis of the precursor of $\mathrm{N}-\mathrm{Cu} / \mathrm{CuO} / \mathrm{C}$ composites, where melamine served as a source of carbon as well as nitrogen when heat treatment was conducted under inert atmosphere [28] [29] [30] [31]. The elemental analysis (CHNS) of $\mathrm{N}-\mathrm{Cu} / \mathrm{CuO} / \mathrm{C}$ revealed the presence of $4.12 \%$ nitrogen and $5.15 \%$, respectively.

\subsection{Catalytic Reduction of RB5}

Figure 3 represents the UV-vis spectra of RB5 and the change of this spectra in the presence of $\mathrm{NaBH}_{4}$ along with/without catalyst $(\mathrm{N}-\mathrm{Cu} / \mathrm{CuO} / \mathrm{C})$. As seen in Figure 3, the pure RB 5 exhibited typical characteristic UV-absorbance peak $\left(\lambda_{\max }\right)$ at $598 \mathrm{~nm}$. However, in presence of $\mathrm{NaBH}_{4}$, the position of the characteristic UV-absorbance peak did not undergo significant change, however, the absorbance reduced to 2.2 (80 ppm) to 1.9 (70 ppm) after 3600 Seconds. However, in the presence of $\mathrm{N}-\mathrm{Cu} / \mathrm{CuO} / \mathrm{C}$ along with $\mathrm{NaBH}_{4}$, the concentration of $\mathrm{RB} 5$ reduced to $2.5 \mathrm{ppm}$.

Optimization of the concentration of $\mathrm{NaBH}_{4}$ during catalytic reduction is an important issue as it governs total reaction efficiency. As it is observed from Figure 3, $\mathrm{NaBH}_{4}$ itself could reduce the concentration of $\mathrm{RB} 5$ to a certain level as it could produce hydrogen via hydrolysis of $\mathrm{NaBH}_{4}$ [22] [32]. To study the effect of concentration of $\mathrm{NaBH}_{4}$ on the reduction of $\mathrm{RB} 5$, several kinetic experiments where the concentration of RB5 and catalyst amount were kept constant and the concentration of $\mathrm{NaBH}_{4}$ was varied. It was reported earlier that the reaction kinetics of the $\mathrm{NaBH}_{4}$ assisted catalytic reduction of organic contaminants could be well represented by pseudo first-order kinetics [22] [33] [34] [35]. As a consequence similar methods have adopted to determine the rate constant.

Figure 4 represents the time courses of RB5 reduction with the variation of the concentrations of $\mathrm{NaBH}_{4}$. The corresponding pseudo-first-order rate constants $\left(k_{\mathrm{app}}\right)$ retrieved from Figure 4 for the reduction of RB5 using 0.2, 0.3 and $0.3 \mathrm{M}$ $\mathrm{NaBH}_{4}$ are $0.059,0.087$, and $0.087 \mathrm{~S}^{-1}$, respectively. The values of $k_{\text {app }}$ increase with an increase of concentration of $\mathrm{NaBH}_{4}$ to $0.3 \mathrm{M}$, however, more increase of $\mathrm{NaBH}_{4}$ concentration did not exhibit higher reduction kinetics. The higher value of RB5 reduction kinetics at higher $\mathrm{NaBH}_{4}$ concentration up to $0.3 \mathrm{M}$ might be ascribed to higher availability of $\mathrm{BH}_{4}^{-}$that worked as a reductant while bonded 
to the catalyst [22] [36]. In the present study, when the $\mathrm{NaBH}_{4}$ concentration exceeded $0.3 \mathrm{M}$, the catalytic surface might be saturated and no more increase in the reduction kinetics of $R B 5$ was witnessed. Consequently, $0.3 \mathrm{M} \mathrm{NaBH}_{4}$ was taken as an optimum concentration for the present study.

Catalytic conversion of $\mathrm{RB} 5$ by $\mathrm{N}-\mathrm{Cu} / \mathrm{CuO} / \mathrm{C}$ and $\mathrm{Cu} / \mathrm{CuO}$ in the presence of $\mathrm{NaBH}_{4}$ is presented in Figure 5(a). When $\mathrm{N}-\mathrm{Cu} / \mathrm{CuO} / \mathrm{C}$ catalyst was used, about $97 \%$ conversion was attained within $315 \mathrm{~s}$, whereas for $\mathrm{Cu} / \mathrm{CuO}$ catalyst, around $25 \%$ conversion was found after $1500 \mathrm{~s}$ reaction. The calculated $k_{\text {app }}$ value of $R B 5$ reduction by $\mathrm{N}-\mathrm{Cu} / \mathrm{CuO} / \mathrm{C}$ was $0.058 \mathrm{~S}^{-1}$ which was much higher than that by $\mathrm{Cu} / \mathrm{CuO}\left(0.023 \mathrm{~S}^{-1}\right.$, See Figure $\left.5(\mathrm{~b})\right)$. The enhanced catalytic activity by $\mathrm{N}-\mathrm{Cu} / \mathrm{CuO} / \mathrm{C}$ over $\mathrm{Cu} / \mathrm{CuO}$ might me for the presence of carbon matrix as well as for the presence of $\mathrm{N}$ moiety which will be discussed in more detail in the next sections.

\subsection{Plausible Mechanisms}

As observed in Figure 6, at the beginning (when $t=0$ ), the UV-Vis Spectra of RB5 is showed two main characteristic peaks at $597 \mathrm{~nm}$ and $313 \mathrm{~nm}$ within visible range along with a small peak at $255 \mathrm{~nm}$ within UV range which is in good agreement with the previous report [34]. The peaks at $597 \mathrm{~nm}, 312 \mathrm{~nm}$, and 254 $\mathrm{nm}$ represent chromophoric $(-\mathrm{N}=\mathrm{N}-)$ group, naphthalene, and benzene rings,

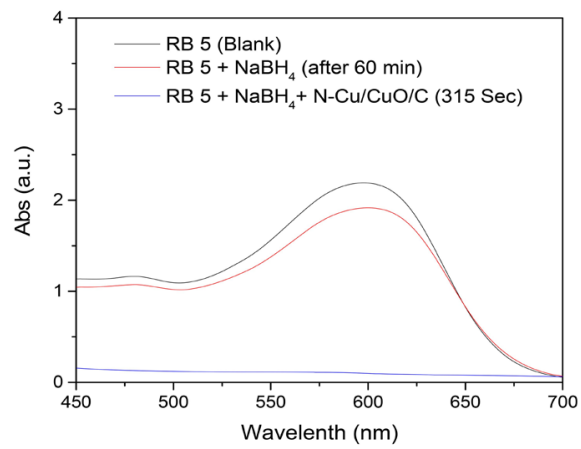

Figure 3. UV-vis spectrum of RB5 (blank); before and after the addition of $\mathrm{NaBH}_{4}$ along with and without the catalyst.

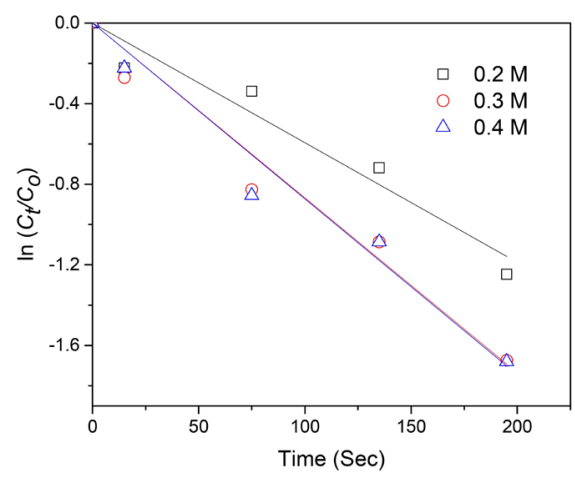

Figure 4. Effect of the concentration of $\mathrm{NaBH}_{4}$ on catalytic reduction of $\mathrm{RB} 5$ by $\mathrm{N}-\mathrm{Cu} / \mathrm{CuO} / \mathrm{C}$ catalyst. 

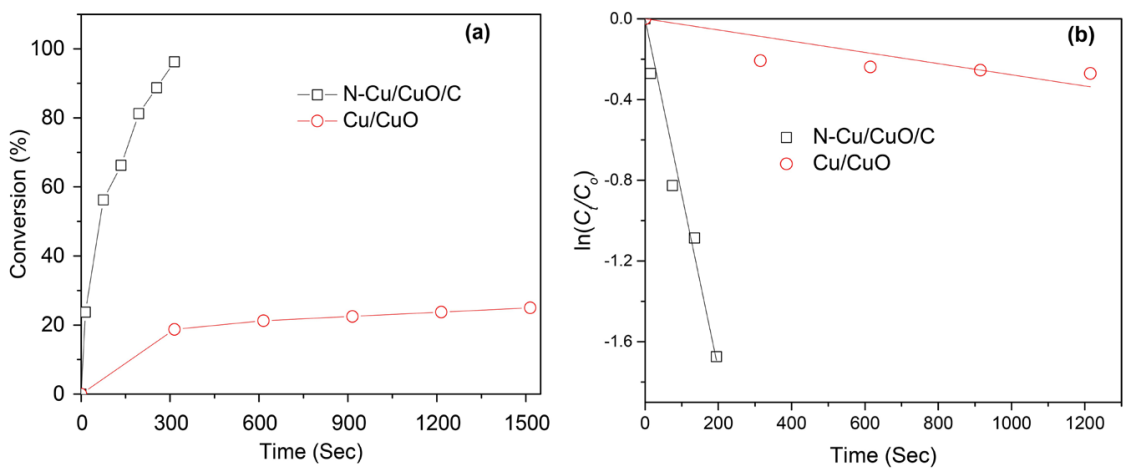

Figure 5. (a) Catalytic conversion of $\mathrm{RB} 5$ by $\mathrm{N}-\mathrm{Cu} / \mathrm{CuO} / \mathrm{C}$ and $\mathrm{Cu} / \mathrm{CuO}$ catalysts; (b) The relationship between $\ln \left(A_{t} / A_{o}\right)$ and reaction time (t) for the reduction of RB5 in presence of $0.2 \mathrm{M} \mathrm{NaBH}_{4}$ by $\mathrm{N}-\mathrm{Cu} / \mathrm{CuO} / \mathrm{C}$ and $\mathrm{Cu} / \mathrm{CuO}$ catalysts.

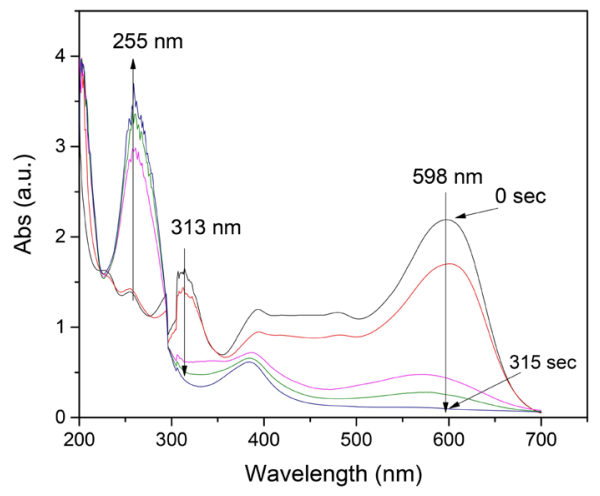

Figure 6. UV-Vis Spectra at various time points during $\mathrm{NaBH}_{4}$ assisted catalytic reduction of RB5 by $\mathrm{N}-\mathrm{Cu} / \mathrm{CuO} / \mathrm{C}$.

respectively [34] [37]. In electrocatalytic reduction, Popli et al. demonstrated that the reductive decomposition of RB5 proceeded via cleavage of azo $(-\mathrm{N}=\mathrm{N}-)$ bond to produce aromatic amines $\left(-\mathrm{NH}_{2}\right.$ groups), such as Sodium 1, 2, 7-triamino-8-hydroxynaphthalene-3,6-disulfonate and Sodium

2-[(4-aminophynyl) sulfonyl] ethyl sulphate [34]. So during the progression of the reduction, the azo bond diminished which resulted in the disappearance peak at $597 \mathrm{~nm}$ (corresponding to azo bond in Figure 6). Sodium borohydride is a well-known strong reducing agent (with standard redox potential $\left(-1.24 \mathrm{E}^{\circ} / \mathrm{V}\right.$ at $\mathrm{pH}$ 14) that has been used to reducing a wide range of redox-active pollutants [18] [38]. However, due to the negative charge on $\mathrm{BH}_{4}^{-}$, it exhibited inadequate applicability to the anionic substance. In aqueous media, $\mathrm{NaBH}_{4}$ hydrolyze $\left(\mathrm{NaBH}_{4}+4 \mathrm{H}_{2} \mathrm{O} \rightarrow \mathrm{NaOH}+\mathrm{H}_{3} \mathrm{BO}_{3}+4 \mathrm{H}_{2}\right)$ to produce $\mathrm{H}_{2}$ that can increase the $\mathrm{pH}$ of the solution [32] [38]. As a consequence, the addition of $\mathrm{NaBH}_{4}$ in $\mathrm{RB} 5$ might increase the $\mathrm{pH}$ over the $\mathrm{pk}_{\mathrm{a}}$ value of RB5 (6.9) [39]. The higher $\mathrm{pH}$ of the solution (over the pKa value of the RB5) might induce speciation which ultimately reduces the probability for the direct reduction due to the development of electronic repulsion between $\mathrm{BH}_{4}^{-}$and anion part of RB5.

It was evident from the previous study that novel metals such as $\mathrm{Ag}, \mathrm{Pt}, \mathrm{Pd}$, etc. played an important role in the enhanced reduction of different pollutants in 
association with $\mathrm{NaBH}_{4}$ [17]. Later, some non-novel metals such $\mathrm{Co}, \mathrm{Ni}, \mathrm{Cu}$, etc. have also demonstrated similar activities. Both for the novel or non-novel metal000 catalyst, the reduction process seemed to follow the same mechanism [18] [22] [32]. In the first step, the accumulation of $\mathrm{BH}_{4}^{-}$and binding $\mathrm{SO}_{3}^{-}$groups of the dye via anchoring the two oxygens (exist in $\mathrm{SO}_{3}^{-}$groups) onto surface $\mathrm{Cu}$ catalyst. In the next step, the electrical reaction between $\mathrm{BH}_{4}^{-}$and $\mathrm{RB} 5$ on the catalyst surface. The surface of the synthesized might play a vital role to establish an electrical connection between $\mathrm{BH}_{4}^{-}$and $R B 5$ and consequently allowing the electrons to travel from the oxidation site to the reduction site [40]. In the case of the $\mathrm{N}-\mathrm{Cu} / \mathrm{CuO} / \mathrm{C}$ catalyst, the active $\mathrm{Cu}$ or $\mathrm{CuO}$ sites are distributed throughout the carbon matrix that might enhance electron travel from the oxidation site to the reduction site. As a consequence, higher conversion RB5 was occurred by $\mathrm{N}-\mathrm{Cu} / \mathrm{CuO} / \mathrm{C}(97 \%)$ compared to that by $\mathrm{Cu} / \mathrm{CuO}(23 \%)$ catalyst. Additionally, different studies revealed that the presence of $\mathrm{N}$ doping in the carbon matrix may enhance the chemical reactivity and electronic density [21]. Consequently, the presence of these supplementary active sites resulted in the improved catalytic activity of $\mathrm{N}-\mathrm{Cu} / \mathrm{CuO} / \mathrm{C}$ composite compared to $\mathrm{Cu} / \mathrm{CuO}$.

\subsection{Reusability}

In consideration of economic as well as environmental aspects, the reusability of a catalyst is an important parameter. As a result, the reusability of best-synthesized catalyst i.e. $\mathrm{N}-\mathrm{Cu} / \mathrm{CuO} / \mathrm{C}$ was assessed by conducting repetitive reduction cycles. After every consecutive cycle, the samples were carefully filtered, washed with ethanol and water, and finally dried to use for the next cycle. After each run, Co-NCC was separated using a magnet and washed with ethanol for regeneration. Figure 7(a) demonstrated the result of $\mathrm{RB} 5$ by $\mathrm{N}-\mathrm{Cu} / \mathrm{Cu} / \mathrm{C}$. As observed in the figure, the $\mathrm{N}-\mathrm{Cu} / \mathrm{Cu} / \mathrm{C}$ catalyst showed superb reusability, steadily keeping more than $96 \%$ conversion up to the last cycle. However, the time needed to complete each cycle increased from $315 \mathrm{~s}$ in the first cycle to $555 \mathrm{~s}$ in the fourth cycle (Figure $7(b)$ ), showing a slight decrease in catalytic efficiency. This decrease in catalytic efficiency might be attributed to the leaching of a small amount of active species, along with the blocking of the active sites.
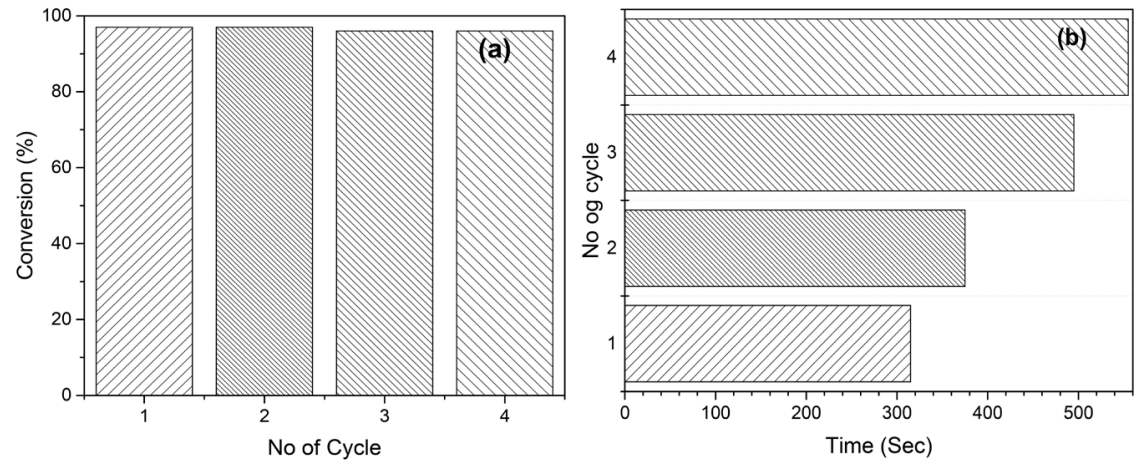

Figure 7. (a) Reusability of $\mathrm{N}-\mathrm{Cu} / \mathrm{CuO} / \mathrm{C}$ catalyst during the reduction of RB5; (b) Time required to accomplish each complete cycle for the reduction of $\mathrm{RB} 5$ by $\mathrm{N}-\mathrm{Cu} / \mathrm{CuO} / \mathrm{C}$. 


\section{Conclusion}

Two Cu-based catalysts were successfully synthesized and their catalytic activity was evaluated via the reduction of RB5 in the presence of $\mathrm{NaBH}_{4}$. Between the two catalysts, $\mathrm{N}-\mathrm{Cu} / \mathrm{CuO} / \mathrm{C}$ exhibited $97 \%$ conversion which is around 4.21 times higher than that of by compared to that of by $\mathrm{Cu} / \mathrm{CuO}$. The apparent reaction rate for $\mathrm{RB} 5$ reduction by $\mathrm{N}-\mathrm{Cu} / \mathrm{CuO} / \mathrm{C}$ was 2.5 times higher than that by $\mathrm{Cu} / \mathrm{CuO}$. The greater catalytic activity of $\mathrm{N}-\mathrm{Cu} / \mathrm{CuO} / \mathrm{C}$ probably originates from the presence of carbon matrix as well as $\mathrm{N}$ moiety. The carbon might boost the electron travel from oxidation to reduction site and the $\mathrm{N}$ moiety might work as an additional active site for the reduction. Besides, $\mathrm{N}-\mathrm{Cu} / \mathrm{CuO} / \mathrm{C}$ also demonstrated good reusability up to four consecutive cycles.

\section{Acknowledgements}

Authors like thank the University of Textile, Bangladesh (BUTEX) for funding the project.

\section{Conflicts of Interest}

The authors declare no conflicts of interest regarding the publication of this paper.

\section{References}

[1] Özcan, A., Ömeroğlu, Ç., Erdoğan, Y. and Özcan, A.S. (2007) Modification of Bentonite with a Cationic Surfactant: An Adsorption Study of Textile Dye Reactive Blue 19. Journal of Hazardous Materials, 140, 173-179. https://doi.org/10.1016/j.jhazmat.2006.06.138

[2] Brillas, E. and Martínez-Huitle, C.A. (2015) Decontamination of Wastewaters Containing Synthetic Organic Dyes by Electrochemical Methods. An Updated Review. Applied Catalysis B: Environmental, 166-167, 603-643. https://doi.org/10.1016/j.apcatb.2014.11.016

[3] Martínez-Huitle, C.A. and Brillas, E. (2009) Decontamination of Wastewaters Containing Synthetic Organic Dyes by Electrochemical Methods: A General Review. Applied Catalysis B: Environmental, 87, 105-145. https://doi.org/10.1016/j.apcatb.2008.09.017

[4] Chong, M.N., Cho, Y.J., Poh, P.E. and Jin, B. (2015) Evaluation of Titanium Dioxide Photocatalytic Technology for the Treatment of Reactive Black 5 Dye in Synthetic and Real Greywater Effluents. Journal of Cleaner Production, 89, 196-202. https://doi.org/10.1016/j.jclepro.2014.11.014

[5] Arslan-Alaton, I., Gursoy, B.H. and Schmidt, J.E. (2008) Advanced Oxidation of Acid and Reactive Dyes: Effect of Fenton Treatment on Aerobic, Anoxic and Anaerobic Processes. Dyes and Pigments, 78, 117-130. https://doi.org/10.1016/j.dyepig.2007.11.001

[6] Copete-Pertuz, L.S., et al. (2018) Decolorization of Reactive Black 5 Dye by Heterogeneous Photocatalysis with $\mathrm{TiO}_{2} / \mathrm{UV}$. Revista Colombiana de Química, 47, 36-44. https://doi.org/10.15446/rev.colomb.quim.v47n2.67922

[7] Ajmal, A., Majeed, I., Malik, R.N., Idriss, H. and Nadeem, M.A. (2014) Principles and Mechanisms of Photocatalytic Dye Degradation on $\mathrm{TiO}_{2}$ Based Photocatalysts: 
A Comparative Overview. RSC Advances, 4, 37003-37026. https://doi.org/10.1039/C4RA06658H

[8] Rafatullah, M., Sulaiman, O., Hashim, R. and Ahmad, A. (2010) Adsorption of Methylene Blue on Low-Cost Adsorbents: A Review. Journal of Hazardous Materials, 177, 70-80. https://doi.org/10.1016/j.jhazmat.2009.12.047

[9] Rajkumar, D. and Kim, J.G. (2006) Oxidation of Various Reactive Dyes with in Situ Electro-Generated Active Chlorine for Textile Dyeing Industry Wastewater Treatment. Journal of Hazardous Materials, 136, 203-212. https://doi.org/10.1016/j.jhazmat.2005.11.096

[10] Song, S., et al. (2007) Mechanism of the Photocatalytic Degradation of C.I. Reactive Black 5 at $\mathrm{pH} 12.0$ Using $\mathrm{SrTiO}_{3} / \mathrm{CeO}_{2}$ as The Catalyst. Environmental Science \& Technology, 41, 5846-5853. https://doi.org/10.1021/es070224i

[11] Lucas, M.S. and Peres, J.A. (2006) Decolorization of the Azo Dye Reactive Black 5 by Fenton and Photo-Fenton Oxidation. Dyes and Pigments, 71, 236-244. https://doi.org/10.1016/j.dyepig.2005.07.007

[12] Vijayaraghavan, K. and Yun, Y.S. (2007) Utilization of Fermentation Waste (Corynebacterium glutamicum) for Biosorption of Reactive Black 5 from Aqueous Solution. Journal of Hazardous Materials, 141, 45-52. https://doi.org/10.1016/j.jhazmat.2006.06.081

[13] Wang, K.S., Chen, H.Y., Huang, L.C., Su, Y.C. and Chang, S.H. (2008) Degradation of Reactive Black 5 Using Combined Electrochemical Degradation-Solar-Light/ Immobilized $\mathrm{TiO}_{2}$ Film Process and Toxicity Evaluation. Chemosphere, 72, 299-305. https://doi.org/10.1016/j.chemosphere.2008.02.012

[14] Rivera, M., Pazos, M. and Sanromán, M.Á. (2011) Development of an Electrochemical Cell for the Removal of Reactive Black 5. Desalination, 274, 39-43. https://doi.org/10.1016/j.desal.2011.01.074

[15] Chen, Y.H., et al. (2005) Ozonation of CI Reactive Black 5 Using Rotating Packed Bed and Stirred Tank Reactor. Journal of Chemical Technology \& Biotechnology, 80, 68-75. https://doi.org/10.1002/jctb.1159

[16] Mohey El-Dein, A., Libra, J.A. and Wiesmann, U. (2003) Mechanism and Kinetic Model for the Decolorization of the Azo Dye Reactive Black 5 by Hydrogen Peroxide and UV Radiation. Chemosphere, 52, 1069-1077. https://doi.org/10.1016/S0045-6535(03)00226-1

[17] Zhao, P., Feng, X., Huang, D., Yang, G. and Astruc, D. (2015) Basic Concepts and Recent Advances in Nitrophenol Reduction by Gold and Other Transition Metal Nanoparticles. Coordination Chemistry Reviews, 287, 114-136.

https://doi.org/10.1016/j.ccr.2015.01.002

[18] Feng, J., et al. (2013) $\mathrm{CuFe}_{2} \mathrm{O}_{4}$ Magnetic Nanoparticles: A Simple and Efficient Catalyst for the Reduction of Nitrophenol. Chemical Engineering Journal, 221, 16-24. https://doi.org/10.1016/j.cej.2013.02.009

[19] Zhu, Y.P., Ren, T.Z. and Yuan, Z.Y. (2014) Hollow Cobalt Phosphonate Spherical Hybrid as High-Efficiency Fenton Catalyst. Nanoscale, 6, 11395-11402. https://doi.org/10.1039/C4NR02679A

[20] Zhang, L., et al. (2015) Magnetic Bimetallic Nanoparticles Supported Reduced Graphene Oxide Nanocomposite: Fabrication, Characterization and Catalytic $\mathrm{Ca}$ pability. Journal of Alloys and Compounds, 628, 364-371. https://doi.org/10.1016/j.jallcom.2014.11.207

[21] Tian, Y., Cao, Y.Y., Pang, F., Chen, G.Q. and Zhang, X. (2014) Ag Nanoparticles Supported on N-Doped Graphene Hybrids for Catalytic Reduction of 4-Nitrophenol. 
RSC Advances, 4, 43204-43211. https://doi.org/10.1039/C4RA06089J

[22] Hasan, Z., Cho, D.W., Chon, C.M., Yoon, K. and Song, H. (2016) Reduction of p-Nitrophenol by Magnetic Co-Carbon Composites Derived from Metal Organic Frameworks. Chemical Engineering Journal, 298, 183-190. https://doi.org/10.1016/j.cej.2016.04.029

[23] Paquin, F., Rivnay, J., Salleo, A., Stingelin, N. and Silva, C. (2013) Metal-Free Catalytic Reduction of 4-Nitrophenol to 4-Aminophenol by N-Doped Graphene. Energy \& Environmental Science, 6, 3260-3266. https://doi.org/10.1039/c3ee40918j

[24] Li, Y., et al. (2015) Facile Synthesis and Capacitive Performance of $\mathrm{Cu} @ \mathrm{Cu}_{2} \mathrm{O} / \mathrm{Graphene}$ Nanocomposites. Ceramics International, 41, 4248-4253. https://doi.org/10.1016/j.ceramint.2014.11.091

[25] Hasan, Z., Cho, J., Rinklebe, J., Ok, Y.S., Cho, D.W. and Song, H.C. (2017) Metal Organic Framework Derived Cu-Carbon Composite: An Efficient Non-Noble Metal Catalyst for Reduction of Hexavalent Chromium and Pendimethalin. Journal of Industrial and Engineering Chemistry, 52, 331-337. https://doi.org/10.1016/j.jiec.2017.04.006

[26] Li, Z., Liu, Y., Guo, D., Guo, J. and Su, Y. (2018) Room-Temperature Synthesis of $\mathrm{CuO} /$ Reduced Graphene Oxide Nanohybrids for High-Performance $\mathrm{NO}_{2}$ Gas Sensor. Sensors and Actuators B: Chemical, 271, 306-310. https://doi.org/10.1016/j.snb.2018.05.097

[27] Muniandy, L., Adam, F., Mohamed, A.R., Iqbal, A. and Rahman, N.R.A. (2017) $\mathrm{Cu}^{2+}$ Coordinated Graphitic Carbon Nitride $\left(\mathrm{Cu}-\mathrm{g}-\mathrm{C}_{3} \mathrm{~N}_{4}\right)$ Nanosheets from Melamine for the Liquid Phase Hydroxylation of Benzene and Vocs. Applied Surface Science, 398, 43-55. https://doi.org/10.1016/j.apsusc.2016.11.103

[28] Gayathri, S., et al. (2019) Mesoporous Nitrogen-Doped Carbon@Graphene Nanosheets as Ultra-Stable Anode for Lithium-Ion Batteries-Melamine as Surface Modifier than Nitrogen Source. Electrochimica Acta, 318, 290-301. https://doi.org/10.1016/j.electacta.2019.06.054

[29] Yang, X., et al. (2020) Nitrogen-Doped Activated Carbons via Melamine-Assisted $\mathrm{NaOH} / \mathrm{KOH} /$ Urea Aqueous System for High Performance Supercapacitors. Materials Chemistry and Physics, 250, Article ID: 123201. https://doi.org/10.1016/j.matchemphys.2020.123201

[30] Yan, X.L., et al. (2018) Melamine as a Single Source for Fabrication of Mesoscopic 3D Composites of N-Doped Carbon Nanotubes on Graphene. RSC Advances, 8, 12157-12164. https://doi.org/10.1039/C8RA01577E

[31] Benavente, E., et al. (2019) Melamine-Assisted Synthesis of Nitrogen-Doped ReS2 Nanosheets/Carbon Composites. Materials Letters, 243, 42-45. https://doi.org/10.1016/j.matlet.2019.01.152

[32] Swathi, T. and Buvaneswari, G. (2014) Application of $\mathrm{NiCo}_{2} \mathrm{O}_{4}$ as a Catalyst in the Conversion of p-Nitrophenol to p-Aminophenol. Materials Letters, 62, 3900-3902. https://doi.org/10.1016/j.matlet.2008.05.028

[33] Pandey, S. and Mishra, S.B. (2014) Catalytic Reduction of p-Nitrophenol by Using Platinum Nanoparticles Stabilised by Guar Gum. Carbohydrate Polymers, 113, 525-531. https://doi.org/10.1016/j.carbpol.2014.07.047

[34] Popli, S. and Patel, U.D. (2017) Mechanistic Aspects of Electro-Catalytic Reduction of Reactive Black 5 Dye in a Divided Cell in the Presence of Silver Nano-Particles. Separation and Purification Technology, 179, 494-503. https://doi.org/10.1016/j.seppur.2017.02.005

[35] Ai, L. and Jiang, J. (2013) Catalytic Reduction of 4-Nitrophenol by Silver Nanopar- 
ticles Stabilized on Environmentally Benign Macroscopic Biopolymer Hydrogel. Bioresource Technology, 132, 374-377.

https://doi.org/10.1016/j.biortech.2012.10.161

[36] Nemanashi, M. and Meijboom, R. (2013) Synthesis and Characterization of Cu, Ag and $\mathrm{Au}$ Dendrimer-Encapsulated Nanoparticles and Their Application in the Reduction of 4-Nitrophenol to 4-Aminophenol. Journal of Colloid and Interface Science, 389, 260-267. https://doi.org/10.1016/j.jcis.2012.09.012

[37] Ben Mbarek, W., Pineda, E., Escoda, L., Suñol, J.J. and Khitouni, M. (2017) High Efficiency Decolorization of Azo Dye Reactive Black 5 by Ca-Al Particles. Journal of Environmental Chemical Engineering, 5, 6107-6113. https://doi.org/10.1016/j.jece.2017.11.032

[38] Demirci, U.B. and Miele, P. (2010) Cobalt in $\mathrm{NaBH}_{4}$ Hydrolysis. Physical Chemistry Chemical Physics, 12, 14651-14665. https://doi.org/10.1039/c0cp00295j

[39] Saroyan, H., Ntagiou, D., Rekos, K. and Deliyanni, E. (2019) Reactive Black 5 Degradation on Manganese Oxides Supported on Sodium Hydroxide Modified Graphene Oxide. Applied Sciences, 9, 2167. https://doi.org/10.3390/app9102167

[40] Zeng, J., Zhang, Q., Chen, J. and Xia, Y. (2010) Properties of Au-Based Nanocages. Nano Letters, 10, 30-35. https://doi.org/10.1021/nl903062e 